\title{
Medical marijuana and beyond
}

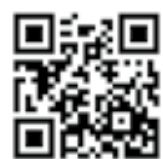

'Legalise marijuana for medical purposes' was the cry in Parliament that prompted the response by Charles Parry and Bronwyn Myers in this issue of SAMJ. ${ }^{[1]}$ Much parliamentary and public sentiment favoured such an action. But is this the wisest course to follow?

The abuse of drugs is harmful to the individual, families and communities. Declaring war on drugs, as US President Nixon did in 1971, therefore has emotional appeal. However, despite this escalating war, the use of drugs has increased worldwide. While the war had noble intentions, it resulted in harmful unintended consequences. Criminalisation of drug use had the effect of hugely increasing the number of prisoners, who are later likely to resort to other criminal activities. The USA, the leader of the war, has the world's highest proportion of jailed citizens (707/100 000, as opposed to South Africa at 294/100 000 and India at 30/100 000). ${ }^{[2]}$ The huge profits from the drug trade corrupt users, politicians, police and financial institutions - the fight for turf by drug cartels in Mexico for drugs destined for the USA has been responsible for tens of thousands of murders and disappearances. While the effects of drugs are harmful, the consequences of the war on drugs are far worse.

Recognition that the war on drugs has failed has resulted in a worldwide shift to review drug policies. ${ }^{[3]}$ These include medicalisation of the use of marijuana in several US states and elsewhere in the world. ${ }^{[1]}$ The change in approach in South Africa is also apparent in the National Drug Master Plan (NDMP) 2013 - 2017 ${ }^{[4]}$ compared with the preceding 2006 - 2011 plan. The latest version aspires to a society free from drug abuse rather than the previous vision of a drug-free society, which does not reflect reality.

The NDMP correctly aspires to use evidence of studies concerning the nature of drugs and of policies to manage them. However, clinical trials are lacking, and the Medicines Control Council would be hard pressed to prepare for medical approval and to identify appropriate indications for it. Furthermore, the approval of marijuana for medical purposes will inevitably result in some fraudulent 'patients', and complicit doctors who provide their scripts.

The NDMP has called for further research, but we already know a great deal. ${ }^{[5]}$ There have been advances in the understanding of addiction and its treatments; drug classification based on its harms can be rational and evidence based; and there are examples of countries that have changed their drug policies with beneficial effects, such as Portugal, which decriminalised the use of all drugs in 2001 with overall improvement across all parameters ${ }^{[6]}$ and Holland, with its success in making marijuana available through designated 'coffee shops. ${ }^{\text {']] }}$

However, commonly voiced concerns about relaxing the war on drugs include:

- South Africa is a developing country and does not have the resources to manage decriminalisation or legalisation. Despite service delivery of all kinds requiring improvement, such a stance invites the obvious rejoinder that we should then give up regulating alcohol and tobacco and policing our traffic laws. Imperfect regulation is better than none.

- Those who want to abolish the war on drugs have not experienced the horrors of addiction. The reality is that addiction occurs, and is increasing, despite increasing intensity of the war on drugs. The stigma resulting from criminalising users and addicts reduces their chances of receiving treatment, and jailing them much increases their chances of becoming habitual criminals.
- The police do not support relaxing the war on drugs. This is understandable, as police are required to enforce existing laws and are promoted for doing so with zeal. But if laws are unjust, they should be changed. Freeing up the police from pursuing innocent users would enable them to focus on more important issues.

- Marijuana is a gateway to the use of more serious drugs. Nutt ${ }^{[5]}$ has noted that 'While it is true that most people who become addicted to heroin and crack have used cannabis, their first drug experiences tend to be alcohol and tobacco,' and that 'If anything, prison is the biggest gateway of all.'

In a previous comment on the March 2011 Anti-Substance Abuse Summit in Durban, Parry and Myers ${ }^{[8]}$ recommend that the government should 'start the real work of formulating and implementing an evidence-based drug policy that learns from the experiences of other countries around decriminalising drug use; takes into account differences in the harms resulting from different classes of drugs; adopts a rights-based, public health approach to policy; and identifies a single (accountable) agency that has the authority to oversee policy implementation'.

Mario Oriani-Ambrosini's recent impassioned plea in Parliament was another wake-up call for action. However, it is probably wiser to get beyond the legalisation of marijuana for medical purposes, which is likely to be a long and complicated process. There is good evidence that decriminalisation of the use of drugs reduces the harms of drugs, reduces the power of the drug lords, and generates revenue for the government. Marijuana is much less harmful than the two legalised drugs, alcohol and tobacco, and has potential medical benefits. A good case can be made for its legalisation and regulation.

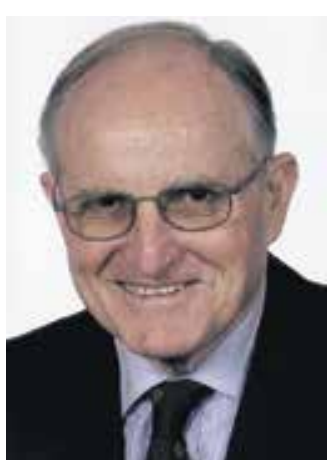
This would also enable the longer and more complicated medical research to proceed legally, and for those who use marijuana for medical or social purposes to do so of their own accord and without persecution.

Bold leadership and action, rather than further revisions of the NDMP, are required.

\section{J P de V van Niekerk \\ Consulting Editor} jpvn@iafrica.com

1. Parry CDH, Myers BJ. Legalising medical use of cannabis in South Africa: Is the empirical evidence sufficient to support policy shifts in this direction? S Afr Med J 2014;104(6):399-400. [http://dx.doi. org/10.7196/SAMJ.8135]

2. International Centre for Prison Studies. http://www.prisonstudies.org/highest-to-lowest (accessed 6 April 2014).

3. Report of the Global Commission on Drug Policy. 2011. http://www.globalcommissionondrugs.org (accessed 8 April 2014).

4. National Drug Master Plan 2013-2017. http://www.dsd.gov.za/index2.php?option=com docman\&task $=$ doc_view\&gid $=414 \&$ Itemid $=3($ accessed 6 May 2014).

5. Nutt D. Drugs Without the Hot Air: Minimising the Harms of Legal and Illegal Drugs. Cambridge: UIT Cambridge, 2012.

6. CATO Institute. Drug Decriminalization in Portugal: Lessons for Creating Fair and Successful Drug Policies. http://www.cato.org/publications/white-paper/drug-decriminalization-portugal-lessons-creatingfair-successful-drug-policies (accessed 10 April 2014).

7. Grund J-P, Breeksma J. Coffee Shops and Compromise: Separated Illicit Drug Markets in the Netherlands. http://www.opensocietyfoundations.org/about/programs/global-drug-policy-program (accessed 12 April 2014)

8. Parry C, Myers B. Beyond the rhetoric: Towards a more effective and humane drug policy framework in South Africa. S Afr Med J 2011;101(10):704-706

S Afr Med J 2014;104(6):387. DOI:10.7196/SAMJ.8335 